\title{
First early Eocene lizards from Spain and a study of the compositional changes between late Mesozoic and early Cenozoic Iberian lizard assemblages
}

\author{
Arnau Bolet
}

\begin{abstract}
Lizard and amphisbaenian fossil material is described for the first time from early Eocene localities in Spain, more specifically from Catalonia (north-eastern Iberian Peninsula). Material is fragmentary and scarce, but diagnostic enough to provide a first approach to the composition of lizard assemblages. The following taxa are recorded: Geiseltaliellus and a second indeterminate pleurodont iguanid; an agamid similar to "Tinosaurus"; an indeterminate gekkotan; a scincoid, possibly scincid lizard; a lacertid similar to Dormaalisaurus; an indeterminate amphisbaenian; a glyptosaurin glyptosaurine (cf. Placosaurus); an indeterminate anguine; and, finally, an indeterminate "necrosaur." The studied localities range from the MP8+9 to the MP10, and thus complement the only previously known lizard locality of the Iberian early Eocene, the Portuguese locality of Silveirinha, which corresponds to the MP7. An analysis of the composition of these new assemblages suggests a great amount of homogeneity through the different levels of the early Eocene, and also between Iberian and contemporaneous assemblages from the rest of Europe. The lack of an Iberian Paleocene record for lizards strengthens the importance of the study of early Eocene assemblages because these are the only ones available for comparison with Cretaceous associations, providing critical information on the changes in composition between Mesozoic and early Cenozoic lizard faunas related to the K/Pg extinction event.
\end{abstract}

Arnau Bolet. Institut Català de Paleontologia Miquel Crusafont, c/ Escola industrial, 23, 08201- Sabadell, Spain. arnau.bolet@icp.cat

Keywords: Reptilia; Squamata; lizards; amphisbaenians; Eocene; Iberian Peninsula

Submission: 29 June 2016 Acceptance: 26 April 2017

Bolet, Arnau. 2017. First early Eocene lizards from Spain and a study of the compositional changes between late Mesozoic and early Cenozoic Iberian lizard assemblages. Palaeontologia Electronica 20.2.20A: 1-22

palaeo-electronica.org/content/2017/1851-early-eocene-lizards 


\section{INTRODUCTION}

The most important early Eocene lizard localities in Europe are situated in Belgium and northern France, the most remarkable exceptions being the locality of Rians in southern France and that of Silveirinha in Portugal. The latter represents all that is known to date of lizard assemblages from this age in southernmost Europe. The Iberian Peninsula, situated at the western edge of Southern Europe, has a good Eocene vertebrate record, but the herpetological fraction that usually accompanies mammals has traditionally been understudied. This is particularly true for small specimens obtained from screen-washing techniques mainly belonging to amphibians, lizards, and snakes, whereas crocodiles and turtles are better known (e.g., Berg and Crusafont, 1970; Ortega et al., 2010; PérezGarcía, 2012; Pérez-García et al., 2013), probably due to a sampling bias resulting from surface collection of larger specimens. The only previously known Iberian Eocene lizard assemblages are those of Silveirinha (early Eocene of Portugal; Rage and Augé, 2003) and Sossís (late Eocene of Catalonia, Spain; Bolet and Evans, 2012a, 2013; Bolet and Augé, 2014). The analysis of several concentrates held at Institut Català de Paleontologia Miquel Crusafont (ICP) revealed the presence of numerous Eocene lizard remains (Bolet and Evans, 2010a), and new material has been recovered in the last years after additional fieldwork. Many of the Eocene localities with samples in the collection are important in yielding fossil primates that have been object of several studies (e.g., Marigó et al., 2013, 2016; Minwer-Barakat et al., 2012, 2013; Femenias-Gual et al., 2016a, 2016b). The present paper concerns those localities of an early Eocene age that have yielded interesting lizard material. The new assemblages reported here cover a previously unstudied range of time (corresponding to levels MP8+9 to MP10) for fossil lizards in the Iberian Peninsula, and add to the known taxonomical diversity contributing, together with ongoing studies on the rest of the paleoherpetofauna, to a better understanding of the paleoenvironmental conditions and paleobiogeography of the Iberian Peninsula during the Eocene.

\section{Geological and Geographical Context of the Studied Localities}

The material studied in this work is housed at Institut Català de Paleontologia Miquel Crusafont, under the acronym IPS. It was recovered at six different localities from Catalonia (North-Eastern Iberian Peninsula): Masia de I'Hereuet; La Morera;
Escarlà; Barranc del Fusteró; Font del Torricó; and La Roca. Masia de l'Hereuet, Barranc del Fusteró and Font del Torricó (the latter is a new locality the geological setting of which will be described elsewhere by members of the ICP) are localities situated in the Àger sub-basin of the Southern Pyrenean Basin. The continental Eocene sediments of the Àger sub-basin were studied by Crusafont-Pairó and Rosell (1966), and mainly consist of marls, clays, and sandstones, with the occurrence of conglomerates in some areas. These continental deposits overlie the marine sediments assigned to earlier levels of the Eocene. Fossil vertebrates are found in the sandstones, which are associated with complex channels of braided rivers, and also in marls and clays corresponding with floodplain deposits (Checa, 1995). The age of Masia de l'Hereuet corresponds to the Neustrian (MP8+9) after Badiola et al. (2009), and its vertebrate fauna is the oldest from the Eocene of Catalonia. Barranc del Fusteró is regarded, however, as MP10 (Badiola et al., 2009), whereas Font del Torricó is a new locality the age of which is preliminarily regarded as early Eocene without more precision. Masia de l'Hereuet is known for having provided fossils of the adapiform primate Agerinia (Marigó et al., 2014) and the plesiadapiform Arcius (Marigó et al., 2012).

Escarlà and La Roca, both corresponding to the MP10 (Antunes et al., 1997), are situated a few kilometres to the northwest of Masia de l'Hereuet, in the Pont the Montanyana area and the Isàbena sub-basin, respectively. La Roca is also known in the literature as Montoliu (Checa and Casanovas, 1990), and Escarlà has provided fossils of the primate Agerinia (Crusafont-Pairó and Golpe-Posse, 1974).

The locality of La Morera (sometimes divided in levels such as La Morera 1, 2, 3.1 and so on, and alternatively named as La Coma in the literature) is situated in the southern portion of the Ebro basin, and it corresponds to the MP10 (Antunes et al., 1997). Information of the level of origin (e.g., La Morera 1, 2, or 3.1) of the specimens are known in some cases, but it has not been used because in most cases the labels only read La Morera, so it was not possible to determine the exact level where they were found. This locality has yielded remains of the primates Cantius and Agerinia (Crusafont-Pairó and Golpe-Posse, 1974).

\section{MATERIAL AND METHODS}

The material consists of small, isolated, and usually incomplete remains of lizards and amphis- 
baenians. Remains corresponding to amphibians and reptiles other than lizards are present in the collection, but have not yet been studied. The lizard collection consists of fragmentary dentaries, maxillae, parietals, vertebrae, and osteoderms. Amphisbaenians are only represented by an almost complete vertebra. The collection is a mixture of specimens recovered at classical localities in the 1990s (see Bolet and Evans, 2010a, 2013) and in recent excavations at some of the same classical sites as well as in a new one (Font del Torricó, see above). Micrographs were taken with an Environmental Scanning Electron Microscope and photographs with a Leica binocular microscope attached to a digital camera.

\section{SYSTEMATIC PALAEONTOLOGY}

The systematic paleontology for the lizard and amphisbaenian assemblage of each locality is treated separately below.

Masia de L'Hereuet (MP7+8, Southern Pyrenean Basin, Àger Sub-basin)

\author{
SQUAMATA Oppel, 1811 \\ IGUANIA Cuvier, 1817 \\ IGUANIDAE Gray, 1827 \\ Genus GEISELTALIELLUS Kuhn, 1944 \\ Geiseltaliellus sp.
}

Figure 1.1-2

Material. IPS 49740, partial left dentary with 10 tooth positons (Figure 1.1); IPS 59535, fragment of right dentary; IPS 83552, partial left maxilla with six teeth (Figure 1.2); IPS 83558, two partial right and two partial left dentaries, one partial maxilla; less certainly IPS 49745, fragment of ?maxilla with two teeth; IPS 83553, partial right dentary.

Description. The most complete dentary (IPS 49740, Figure 1.1) is long and slender, with a subdental shelf that has a rounded lingual margin and, at least in its posterior portion, has a limited lingual projection under the tooth bases. A sulcus dentalis is absent. The ventral margin of the dentary is broad, and both margins approach each other in the anterior preserved part. The bone preserves 10 tooth positions, of which only two teeth are complete, one of them well-preserved. In these two teeth, the crowns are clearly tricuspid, with a central larger cusp and two additional equally sized cusplets situated in anterior and posterior positions. The projection of the teeth above the parapet of the dentary is more than one third of the tooth height. Two small labial foramina are observable on the labial surface of the preserved fragment of dentary. The maxillae (IPS 83552, Figure 1.2; IPS 83558 in part, ?IPS 49745) bear teeth that replicate those of IPS 49740. In IPS 83552 the central tooth is perpendicular to the supradental shelf, whereas the anterior ones are posteriorly inclined and the posterior ones are anteriorly inclined. This is not the case of the maxilla in IPS 83558 (not figured), where the teeth are strictly straight and also higher. Remarks. The morphology of the Meckelian canal, open in the preserved region, but with approaching margins anteriorly, together with the lack of sulcus dentalis and the presence of tricuspid teeth allows identification of a pleurodont iguanid, and this form specifically fits well with the genus Geiseltaliellus (see diagnosis in Augé, 2005). A few North American Eocene iguanids bear dentaries with a similar morphology of the Meckelian canal (e.g., Oreithyia, Suzanniwana and Parasauromalus; see Smith, 2011a and Smith and Gauthier, 2013) but are less likely related to the material described herein based on biogeographical and temporal grounds. Despite being very close in size and morphology to contemporaneous species $\mathrm{G}$. longicaudus, material is insufficient to make a referral at the species level. The fragments of maxillae are tentatively referred to the same taxon on the basis of tricuspidy, size and overall morphology of the best preserved teeth.

$$
\begin{gathered}
\text { ACRODONTA Cope, } 1864 \\
\text { AGAMIDAE Gray, } 1827 \\
\text { Agamidae indet. } \\
\text { Figure 1.5-6 }
\end{gathered}
$$

Material. IPS83546, fragment of tooth-bearing bone with one tooth (Figure 1.5); IPS83543, fragment of left dentary with two teeth (Figure 1.6).

Description. Material comprises two small toothbearing bones with labiolingually compressed tricuspid teeth (one large central cusp and two much smaller cusps at both sides) and an acrodont implantation (Figure 1.5 and 1.6).

Remarks. Material is scarce and very fragmentary, but highly diagnostic for acrodontan iguanians and compares well with contemporaneous European agamids. The presence of agamids in the early Eocene of Europe including those from other western European Paleogene localities was reviewed by Augé (2005). However, the presence of agamids in the Iberian Paleogene has been limited to the early Eocene of Silveirinha, where they are represented by a single fragmentary specimen tentatively referred to "Tinosaurus" (Rage and Augé, 2003). The fragmentary nature of the Portuguese material and the new Catalan specimens precludes a detailed comparison and a discussion on their 


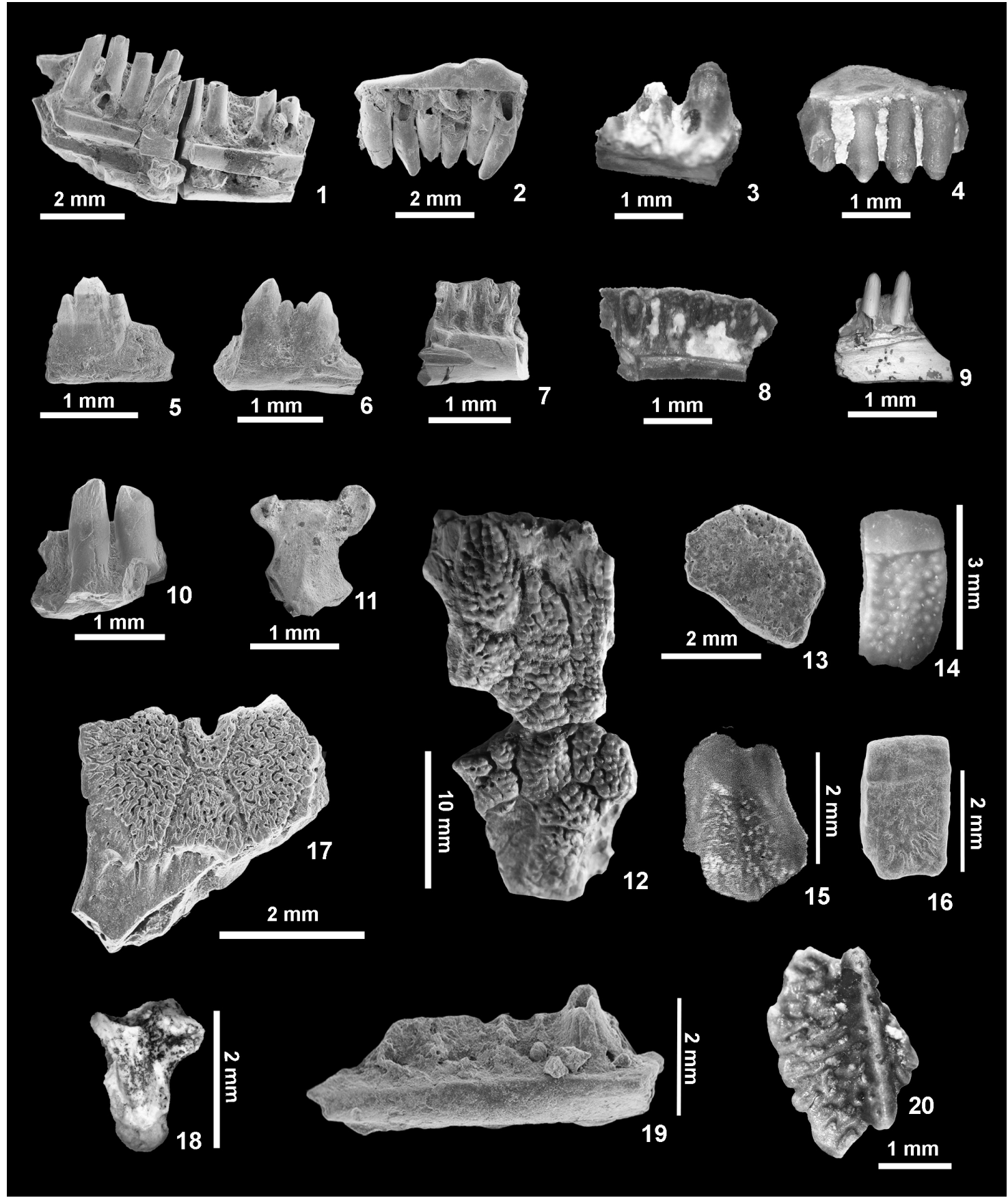

FIGURE 1. Selected lizard and amphisbaenian material from studied localities. 1-2, Geiseltaliellus sp.: 1, left dentary (IPS 49740); 2, maxilla (IPS 83552); 3-4, Iguanidae indet.: 3, fragment of dentary (IPS 83535) with one preserved tooth, 4, fragment of ?maxilla with four preserved teeth (IPS 49756); 5-6, Agamidae indet.: 5, Fragment of toothbearing bone preserving one tooth (IPS 83546), 6, fragment of dentary preserving two teeth (IPS 83543). 7-8, Gekkota indet:: 7, posterior portion of left dentary (IPS 59559), 8, anterior portion of left dentary (IPS 83520); 9, Scincoidea (?Scincidae) indet., fragment of right dentary (IPS 49752); 10, ?Lacertidae indet., fragment of tooth-bearing bone perserving two teeth (IPS 49762); 11, Amphisbaenia indet., vertebra (IPS 59529); 12, cf. Placosaurus sp., partial parietal with fused osteoderms (IPS 59567); 13, Glyptosaurini indet., skull osteoderm (IPS 83532); 14, Glyptosaurinae indet., body osteoderm (IPS 83533); 15-18, Anguinae indet.: 15, keeled body osteoderm (IPS 83540), 16, unkeeled body osteoderm (IPS 83533), 17, partial parietal (IPS 83557), 18, vertebra (IPS 59538); 19-20, "Necrosauridae" indet.: 19, partial left dentary (IPS 83545), 20, osteoderm (IPS 49741). 1, 2, 5, 6, 11, 15 and 17-20 from Masia de l'Hereuet (MP8+9); 3, 4, 7, 8, 10 and 14 from La Morera (MP10); 12 from Escarlà (MP10); 13 and 16 from Font del Torricó. 1-10 and 19 in labial view; 11-12, 17 in dorsal view; 13-16 and 20 in external view; 18 in ventral view. 
possible affinities beyond Agamidae. Despite a slightly different tooth morphology of the specimens from both Iberian localities, they are more similar to each other and to "Tinosaurus" europeocaenus (Augé and Smith, 1997) than to later European forms like Quercygama or Uromastyx, mainly regarding tooth morphology. However, according to Smith (2011b) the polyphyly of "Tinosaurus" cannot be excluded (see also Smith et al., 2011), and material from Silveirinha, as well as that from Masia de l'Hereuet, is best regarded as belonging to an indeterminate agamid.

\section{"SCINCOMORPHA" Camp, 1923 \\ "Scincomorpha" indet.}

Material. IPS 49743, fragment of ?maxilla bearing two teeth; IPS 83544, fragment of left dentary with four teeth (three of them are broken).

Description. The teeth of IPS 83544 are high, columnar, and the best preserved crown appears simple (allowing for the lack of the tip, which is broken). The presence of some sort of lateral shoulders is inferred from the region immediately below the breakage surface. The subdental shelf has a high lingual surface, and the open Meckelian canal opens mostly ventrally. A complete tooth of IPS 49743 (1 mm high) shows a columnar shape, a crown that is slightly posteriorly directed, and wellmarked lingual striae that run along the most distal third of the tooth height.

Remarks. "Scincomorpha" is a paraphyletic group after molecular and combined-evidence studies (e.g., Townsend et al., 2004; Vidal and Hedges, 2009; Wiens et al., 2010; Jones et al., 2013; Pyron et al., 2013) but the name is used in quotes here to group non-anguimorphan autarchoglossans sensu Estes et al. (1988), following the scheme recovered by most morphological studies. The open Meckelian canal and the closely packed (but not crowded) teeth both argue against a referral to Gekkota. The simple, conical teeth, probably presenting shoulders are typical of scincoids. The poor preservation of the dentition in IPS 49743 does not allow the determination of the presence or absence of a cuspis labialis and lingualis, but an antrum intercristatum seems to have been absent. In any case, the overall shape of the dentition suggests "scincomorphan" affinities.

\section{SCINCOIDEA Oppel, 1811 Scincoidea indet.}

Material. IPS 49761, fragment of tooth-bearing bone with one tooth (not figured).

Description. The fragment of bone attached to the tooth does not allow differentiation between a max- illa and a dentary. The tooth is, however, well-preserved, except for the tip. It presents the typical shape of scincoids, with two main striae (stria dominans anterior and stria dominans posterior; sensu Richter, 1994) presumably converging in a cuspis labialis (not preserved).

Remarks. The lack of a well-developed antrum intercristatum would favour cordyliform affinities, but this character is not conclusive (some scincids lack a well-developed antrum intercristatum; see Kosma, 2004), and the specimen is too fragmentary to provide a more precise determination.

\section{AMPHISBAENIA Gray, 1844 Amphisbaenia indet. \\ Figure 1.11}

Material. IPS 59529, dorsal vertebra (Figure 1.11). Description. IPS 59529 is very small $(1 \mathrm{~mm}$ wide at the level of the prezygapophyses), and presents the typical amphisbaenian configuration: it is strongly dorso-ventrally compressed, it lacks a neural spine, and has a flat ventral surface. The cotyle and condyle (allowing for a partial preservation of the latter) are both dorso-ventrally compressed.

Remarks. Amphisbaenians are abundant at European Paleogene localities since the Late Paleocene, with the exception of the greatest part of the Middle Eocene (Augé, 2012). It is difficult to assess which or how many taxa are present in the Eocene. At least one form, recently described as Blanosaurus (Folie et al., 2013) is probably close to Blanus (i.e., probably belongs to Blanidae). Although it can be stated that the isolated vertebra from Masia de l'Hereuet does not belong to a rhineurid (it lacks a posteromedian notch), it is best referred to indeterminate amphisbaenians because it is not possible to ascertain if it is closer to Blanidae than to other amphisbaenians. The presence of an additional, exclusively fossil group, in the Paleogene of Europe (the polyodontobaenids; Folie et al., 2013), and the identification of Amphisbaenidae in the Early Oligocene of Valbro (Rage and Augé, 2015), adds complexity to the issue and highlights a greater diversity of amphisbaenians than previously recognised. However, as said above, the posterior border of its neural arch seems to lack a median notch, whereas an indentation is present in Trogonophiidae, Rhineuridae, and most Amphisbaenidae (Rage and Augé, 2015), including the form from Valbro, suggesting that Blanidae might be the best candidate for the early Eocene Iberian material. 
ANGUIMORPHA Fürbringer, 1900 ANGUIDAE Gray, 1825

GLYPTOSAURINAE Marsh, 1872

GLYPTOSAURINI Sullivan, 1979

Glyptosaurini indet.

Material. IPS 3742, partial skull osteoderm.

Description. IPS 3742 is a partial dome-like and thick skull osteoderm.

Remarks. When they are present, skull hexagonal osteoderms indicate the presence of a member of the tribe Glyptosaurini (Augé, 2005). "Melanosaurini," the other tribe (possibly paraphyletic; see Sullivan et al., 2012) that forms Glyptosaurinae, is at its turn characterized by sub-divided, plate-like cephalic osteoderms in the skull (Sullivan, 1979; Sullivan et al., 2012). Despite not being the typical hexagonal skull osteoderm of Glyptosaurini, IPS 3742 is too thick and with too well-defined margins to represent a member of "Melanosaurini."

Glyptosaurinae indet.

Material. IPS 35741, three fragments of body osteoderm; IPS 49738 fragment of body osteoderm; IPS 59536, four fragments of body osteoderms; IPS 83547, seven body osteoderms or fragments of body osteoderms, one partial skull osteoderm; IPS 83549, 10 body osteoderms and fragments of osteoderm; IPS 49744, tooth-bearing bone (?dentary) fragment with one tooth; IPS 83539, several dozen osteoderms; IPS 83551, four fragments of osteoderms; IPS 83554, body osteoderms.

Description. These body osteoderms are rectangular, bevelled, and range from unkeeled to weakly keeled. They bear a well-marked external tuberculated ornamentation. The largest osteoderm is 7 $\mathrm{mm}$ long but it is only partially preserved, so its actual length could have reached $10 \mathrm{~mm}$ or even more. The rest of the osteoderms are usually much smaller. Rounded and irregular osteoderms are present, but less abundant. The thicker osteoderms, usually attached to bone, are interpreted as cranial osteoderms, but are too fragmentary to infer their shape.

IPS 49744 is a possible dentary fragment (not figured) with one well-preserved robust tooth. The crown is labiolingually compressed but is not pointed but forming a straight anteroposteriorly directed edge. The base of the tooth is labiolingually expanded, and the apical lingual surface of the crown presents few well-marked and parallel striae.

Remarks. Glyptosaur osteoderms are present in most Eocene localities from Europe, but they are not diagnostic in the absence of hexagonal or polygonal cranial osteoderms or well-preserved dentaries or maxillae. When they are present, skull hexagonal osteoderms indicate the presence of a member of the tribe Glyptosaurini (Augé, 2005). "Melanosaurini," the other tribe (possibly paraphyletic; see Sullivan et al., 2012) that forms Glyptosaurinae, is at its turn characterized by rectangular and not so well-defined osteoderms in the skull. However, body osteoderms are rectangular in both cases and do not serve to discriminate between the two tribes. Material from Masia de l'Hereuet is too fragmentary to give any information at the tribe level, and is thus referred to Glyptosaurinae.

\section{ANGUINAE Gray, 1825 \\ Anguinae indet. \\ Figure 1.15, 1.17-18}

Material. IPS 83557, partial parietal (Figure 1.17); IPS 59538, two partial vertebrae (Figure 1.18); IPS 83540, two body osteoderms.

Description. The parietal is very small (ca. $4 \mathrm{~mm}$ wide at its widest point), and presents the typical ornamentation of non-glyptosaur anguids, with ridges, grooves, and pits. It is anteriorly broken at the level of the parietal foramen (which completely pierces the bone) and, posteriorly, the fracture runs obliquely only preserving the basal part of the supratemporal left process. Dorsally, the lateral osteodermal shields are anteroposteriorly elongated, with a narrow medial posterior (occipital) shield, and two reduced and poorly defined postero-lateral shields. The body osteoderms present the typical anguine ornamentation on their external surface. The largest one barely reaches $3 \mathrm{~mm}$ long. One of them is keeled, and the other one (Figure 1.15) is not. Both vertebrae (Figure 1.18) present the typical anguine configuration, being dorsoventrally compressed, with a flattened condyle, and a narrow dorsal spine.

Remarks. Three different types of remains confirm the presence of non-glyptosaur anguids at Masia de l'Hereuet: a single parietal, two osteoderms, and two vertebrae. These remains most closely resemble those of anguines, which are otherwise the only non-glyptosaur anguid group recorded in Europe. The low abundance of anguine osteoderms in the early Eocene of Europe, despite the reported presence of anguines based on other skeletal elements (namely vertebrae and dentaries), is intriguing. As an example, Prémontré (MP10, France) is a well-sampled locality that has only yielded few anguine osteoderms (Augé, 2003). The same is true for Masia de l'Hereuet. In any case, it is clear that two osteoderms represent 
an unusually low number for a locality where the presence of anguines is well established, mainly if compared to younger Paleogene localities. The parietal represents the earliest record of this element for a European anguine. This element is of high diagnostic power (see Klembara and Green, 2010) and might be of importance to establish the exact affinities of the taxon from Masia de l'Hereuet with other anguines from the Cenozoic of Europe. It is only slightly larger than that of the miniaturised Headonhillia from the late Eocene of the United Kingdom (see Klembara and Green, 2010), but it clearly differs from it in the presence of a long occipital shield (it is wider than long in Headonhillia). It also differs from Anguis in having a long area levis. Unfortunately, the presence of a crista postfovealis cannot be confirmed, which would have refuted a referral to Ophisaurus and Anguis (see Sullivan et al., 1999). A deeper study of the anguine material from Masia de l'Hereuet is expected to yield interesting information, mainly if additional material is recovered, but a general resemblance to Ophisaurus and Ophisauriscus is favoured.

VARANOIDEA Camp, 1923

"NECROSAURIDAE" Hoffstetter, 1943

"Necrosauridae" indet.

Figure 1.19-20

Material. IPS 83545, fragment of dentary (Figure 1.19); IPS 49741, partial osteoderm (Figure 1.20).

Description. IPS 83545 is a fragment of dentary preserving one incomplete tooth. The tip of the crown is broken, so it is not possible to ascertain if the tooth was originally recurved. The presence of plicidentine is clear at the base of the preserved tooth. IPS 49741 (Figure 1.20) is a partially preserved oval osteoderm with a strong ornamentation formed by pits and ridges, and dorsally presents a high, rather rounded, longitudinal keel.

Remarks. The morphology of IPS 49741 recalls that of osteoderms referred to the genus Necrosaurus from contemporaneous localities from Europe (e.g., Condé-en-Brie; see Augé 2005), although it is also reminiscent of osteoderms of Shinisaurus and Provaranosaurus (see Smith and Gauthier, 2013). However, the osteoderm morphology together with the presence of a fragment of dentary presenting plicidentine and strongly resembling that of Necrosaurus suggests the presence of a "necrosaur" at Masia de l'Hereuet.

Indeterminate lizards (non-ophidian, nonamphisbaenian squamates)
Material. IPS 49742, fragment of left dentary; IPS 49746 , anterior portion of a right dentary with two teeth; IPS 59530, vertebra; IPS 59532, tooth; IPS 59539 , tooth; IPS 83542, seven fragments of toothbearing bones; IPS 83548, four fragments of dentary; IPS 83550, two fragments of tooth-bearing bone; IPS 83541, roughly rounded osteoderm.

Description. This material, including tooth-bearing bones and partial vertebrae, is fragmentary and/or poorly diagnostic, making its referral to a specific lizard family impossible. The osteoderm, IPS 83541 , is roughly rounded, partially bevelled, not ornamented, and bearing few foramina and channels on the external surface, and only two foramina on the internal surface.

Remarks. These specimens are listed here because the eventual recovery of additional betterpreserved material might make them identifiable in the future. IPS 83541 deserves further attention because apparently it does not belong to any of the forms from the locality bearing osteoderms (glyptosaurs, anguines, "necrosaurs"), and may represent an additional, possibly anguimorphan, unidentified form at Masia de l'Hereuet.

\section{Font del Torricó (Early Eocene, Southern Pyrenean Basin, Àger Sub-basin)}

\author{
IGUANIA Cuvier, 1817 \\ IGUANIDAE Gray, 1827 \\ Iguanidae indet.
}

Material. IPS 83531, fragment of tooth bearing bone with two tricuspid teeth.

Description. A poorly preserved fragment of bone preserving two pleurodont, high, and columnar teeth. The crowns bear three cusps, although one of the lateral cusplets is in both cases somewhat worn. No striae are present in the crowns. The subdental shelf barely extends lingually below the tooth bases and, accordingly, there is no sulcus dentalis.

Remarks. The tricuspid condition and overall morphology of the crowns, together with the lack of a sulcus dentalis suggest iguanian affinities for IPS 83531 (not figured). Morphology is close to that of Geiseltaliellus but this specimen is somewhat more robust than other specimens from the Catalan localities. It is not clear, however, if this is related to its slightly larger size (and thus probably related to ontogeny) or, alternatively, to differences at the genus level. The fragmentary nature of this specimen only grants identification of a pleurodont iguanian at Font del Torricó.

\section{ANGUIMORPHA Fürbringer, 1900 ANGUIDAE Gray, 1825}




\section{ANGUINAE Gray, 1825 \\ Anguinae indet. \\ Figure 1.16}

Material. IPS 83533, body osteoderm (Figure 1.16); ?IPS 83537, two fragments of vertebrae (condyles).

Description. The only recovered body osteoderm is $2.5 \mathrm{~mm}$ long. It is rectangular and bevelled, with the gliding surface occupying one third of its length (Figure 1.16). It presents an ornamentation of pits and ridges typically found in anguines. The external ornamented surface bears a faint keel. The two condyles (IPS 83537) are dorsoventrally depressed and the preserved portion in one of the vertebrae suggests the centrum was narrow and with parallel lateral margins. One of the centra is significantly larger than the other one.

Remarks. The single osteoderm is the best proof of the presence of anguines at Font del Torricó. The ornamentation presented by this element only fits with anguines among the fossil European taxa with which it was compared, although it is slightly different from that of anguine osteoderms from Masia de l'Hereuet and Barranc del Fusteró, suggesting the presence of a second anguine in the early Eocene of Catalonia. Material recovered so far is, however, very limited and precludes a deeper discussion on its affinities. The fragments of vertebrae present some characters of anguine vertebrae, but their fragmentary nature makes a referral to Anguinae much more dubious.

\section{GLYPTOSAURINAE Marsh, 1872 \\ GLYPTOSAURINI Sullivan, 1979 \\ Glyptosaurini indet.}

Figure 1.13

Material. IPS 83532, two cranial osteoderms, one fragment of osteoderm (Figure 1.13).

Description. The three osteoderms referred to Glyptosaurinae bear the typical ornamentation of small tubercles. One of the osteoderms (Figure 1.13) is polygonal (?hexagonal), clearly corresponding to the skull, and relatively flat. A second one is more irregular and relatively thick. Its irregular shape and the lack of a gliding surface also suggest that it corresponded to the region of the skull. The third osteoderm bears the same ornamentation as the other two, but it is poorly preserved.

Remarks. The presence of osteoderms with an ornamentation formed of tubercles can only be linked to the presence of Glyptosaurinae, and the presence of clearly polygonal skull osteoderms is typical of the tribe Glyptosaurini. It has to be noted that the figured specimen is slightly more flat than those of the parietal from Escarlà described below and referred to cf. Placosaurus. Skull osteoderms from the late Eocene of Sossís and referred to Glyptosaurini by Bolet and Evans (2013) are much thicker.

\section{Barranc del Fusteró (MP10, Southern Pyrenean Basin, Àger Sub-basin)}

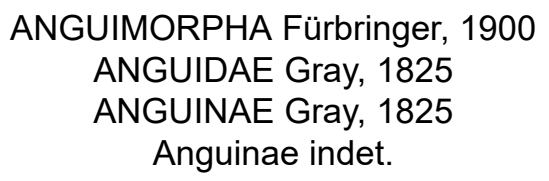

Material. IPS 49860, three fragments of osteoderm; IPS 49862, fragment of osteoderm.

Description. The three fragments of osteoderm corresponding to IPS 49860 (not figured) present the typical ornamentation of pits and ridges found in anguines. They are too fragmentary to provide much information on their outline, but one of them suggests it was roughly elliptical. Two of them bear well-developed gliding surfaces. IPS 49862 is more poorly preserved and only tentatively referred to Anguinae on the basis of overall shape and ornamentation (the surface is worn).

Remarks. The fragmentary nature of these specimens precludes any discussion on their affinities, except that their ornamentation is more similar to the anguine specimens from Masia de l'Hereuet than to that from Font del Torricó.

\section{GLYPTOSAURINAE Marsh, 1872 \\ Glyptosaurinae indet.}

Material. IPS 49863, body osteoderm.

Description. This small osteoderm (not figured) has the typical tuberculated ornamentation of glyptosaurines. The dorsal surface presents a laterally displaced faint keel.

Remarks. The presence of a keel suggests that this osteoderm corresponded to the body. Accordingly, it cannot be referred to one of the tribes in front of the other, and is thus referred to Glyptosaurinae.

Escarlà (MP10, Southern Pyrenean Basin, Tremp-Grauss Sub-Basin, Pont de Montanyana Area)

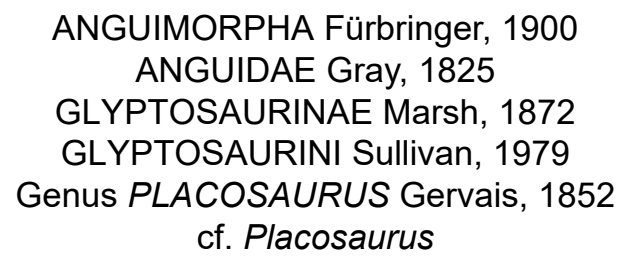

Material. IPS 59567 (Figure 1.12), partial parietal. 
Description. The single specimen from this locality corresponds to a left half of a parietal table with fused tubercular osteoderms. The latter are polygonal (one of them might have been hexagonal, but preservation precludes a definite statement), relatively flat, and not conical. The tubercles are irregularly arranged on the dorsal surface of the osteoderms. Ventrally, the presence of a medial ridge can be ascertained in the preserved portion of the parietal. The anterior portion of a left lateral ridge is also preserved, but it rapidly reaches the limit of preserved margin of the bone. No parietal foramen is observable because it would have been in the poorly preserved medial margin of the bone.

Remarks. The presence of cranial isolated polygonal osteoderms supports a referral to the tribe Glyptosaurini, and not the "Melanosaurini" (Sullivan, 1979). Moreover, the parietal compares well with the contemporaneous parietal referred to ?Placosaurus ragei by Sullivan et al. (2012). Sullivan et al. (2012) suggested that the lack of osteoderms in the periphery of the parietal they tentatively referred to ?Placosaurus ragei was either a primitive or a juvenile trait. The parietal described here is not well-preserved in its lateral margins, but some osteoderms seem to be lacking even in non-peripherical positions. The fact that failure to fusion occurs also in non-peripherical positions (in contrast to the Dormaal specimen) suggests a certain degree of variability in the degree of fusion of osteoderms to the parietal table. This also occurs in the frontal of Placosaurus estesi, where at least one osteoderm by the side of the midline is missing (see Sullivan and Augé, 2006), and osteoderms close to the anterior, posterior and lateral margins are also lacking. Referral of the specimen from Escarlà to Glyptosaurini is well supported, and referral to Placosaurus seems likely, although it is regarded as tentative.

\section{La Roca (MP10, Southern Pyrenean Basin, Isàbena Sub-Basin)}

\author{
IGUANIA Cuvier, 1817 \\ IGUANIDAE Gray, 1827 \\ Iguanidae indet.
}

Material. IPS 9093, A fragment of ?dentary.

Description. A fragment of tooth-bearing bone preserving five tricuspid teeth.

Remarks. The tricuspid nature of the preserved teeth as well as resemblance to the genus Geiseltaliellus suggest the presence of this pleurodont iguanian at this locality. However, the fragmentary nature of the specimen does not allow a formal referral to the genus.

\section{La Morera (MP10, Ebro Basin)}

\author{
IGUANIA Cuvier, 1817 \\ IGUANIDAE Gray, 1827 \\ Iguanidae indet. \\ Figure 1.3-4
}

Material. IPS 83535, fragment of tooth-bearing bone with one preserved and one broken tooth (Figure 1.3); IPS 49756 (Figure 1.4), fragment of maxilla with four teeth; IPS 83522, fragment of tooth-bearing bone with two preserved teeth; IPS 83534 , fragment of tooth-bearing bone with one unicuspid tooth and one tricuspid tooth; IPS 49766, fragment of tooth-bearing bone with one preserved tooth.

Description. The small fragment of maxilla IPS 83535 bears one tricuspid tooth. The central cusp is much larger and rounded, the accessory cusps being very small and pointed. The same description is valid for IPS 49756, but this bone is larger, and the tooth tips are worn so that its tricuspidy is less evident.

Remarks. The tricuspidy of these bones point to the presence of a second pleurodont iguanian at La Morera. It differs from Geiseltaliellus by its more robust dentition, teeth that are implanted orthogonal to the dental shelf, a more rounded central cusp, and less marked lateral cusplets. The presence of Geiseltaliellus is, however, not completely discarded at La Morera, as IPS 83534 (not figured) bears teeth that approach the slender dentition of this ubiquitous iguanid genus. However, it is better identified as an indeterminate iguanian at this time, but note that two different forms, one of them close to Geiseltaliellus, might be present at La Morera. It is also acknowledged that the poor preservation of the crowns of IPS 83535 hinders comparison, and it is not discarded that it could represent a different taxon.

\section{GEKKOTA Cuvier, 1817 Gekkota indet. \\ Figure 1.7-8}

Material. IPS 49754, fragment of right dentary; IPS 59559 , posterior portion of left dentary (Figure 1.7); IPS 83520 fragment of left dentary (Figure 1.8); IPS 83521, fragment of right dentary.

Description. These dentaries present a closed Meckelian canal and slender and closely packed teeth. None of the teeth are completely preserved, precluding a description of tooth crowns. It can be stated, however, that teeth were less numerous and crowded than is average for gekkotans. A very deep facet for the splenial is present in IPS 59559. 
Remarks. The combination of a completely closed Meckelian canal and closely packed teeth point to the presence of a gekkotan at La Morera. The consistency in size and morphology of the three specimens points to a single form. The recovery of additional material would allow comparisons with the scarce material from Silveirinha (see Rage and Augé, 2003) and, more interestingly, with the Late Eocene material from Sossís, which comprises three different gekkotan forms (Bolet and Evans, 2013).

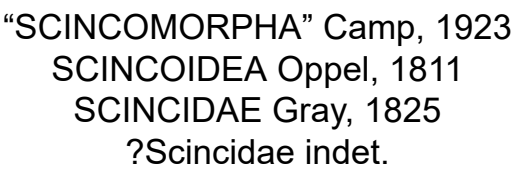

Figure 1.9

Material. IPS 49752, right dentary fragment with two preserved teeth (Figure 1.9); IPS 49753, ?maxilla fragment with two preserved teeth; IPS83527, posterior portion of left dentary.

Description. The teeth of IPS 49752 are wellspaced and posteriorly inclined. They are columnar and present the typical scincoid configuration, with a lingually and a labially positioned cusp (cuspis lingualis and labialis sensu Richter, 1994). Between them there is a sulcus, the antrum intercristatum sensu Kosma (2004). The crowns do not bear striae. The tooth crowns of IPS 49753 are very similar, but instead are rather orthogonal, not posteriorly inclined. The tips of the crowns in IPS 59548 are not well-preserved, but the overall shape of the dentition is similar to that of IPS 49753.

Remarks. The presence of Scincoidea at La Morera is clear after these specimens. Material is too fragmentary to allow more concrete determinations, but the morphology of the crowns is similar to that figured for the scincid Lipinia noctua (Kosma, 2004, plate VII, figure 1) and would suggest the presence of Scincidae rather than Cordyliformes. The material is clearly different from Scincoideus (Folie et al., 2005) in that the lingual cusp is large for La Morera specimens, and the separation between teeth is large, against the more close packing of the teeth of Scincoideus. The presence of a well-developed antrum intercristatum is more widespread among scincids, but because it is seldom present in cordyliforms (as well as other scincomorphans; see Kosma, 2004), a formal referral to Scincidae is, despite being the most probable option, not possible at this time.

$$
\begin{aligned}
& \text { LACERTIFORMES Estes et al., } 1988 \\
& \text { LACERTIDAE Bonaparte, } 1831
\end{aligned}
$$

\section{?Lacertidae indet.}

Figure 1.10

Material. IPS 49762, fragment of maxilla with two preserved teeth (Figure 1.10).

Description. This bone presents a robust pleurodont dentition. The bases of the teeth are labiolingually expanded, and there is a shoulder (not a true secondary cusplet) in an anterior position to the main cusp.

Remarks. The morphology of the best-preserved tooth, presenting an anteriorly positioned shoulder, fits well with that of the contemporaneous lacertid Dormaalisaurus Augé and Smith, 2002. However, the poor preservation of the specimen from La Morera precludes further comparisons, and only the presence of a possible lacertid is granted.

$$
\begin{aligned}
& \text { ANGUIMORPHA Fürbringer, } 1900 \\
& \text { ANGUIDAE Gray, } 1825 \\
& \text { GLYPTOSAURINAE Marsh, } 1872 \\
& \text { GLYPTOSAURINI Sullivan, } 1979 \\
& \text { Glyptosaurini indet. }
\end{aligned}
$$

Material. IPS49750, cranial osteoderm.

Description. The only skull osteoderm is polygonal, unkeeled, not bevelled, and it bears an ornamentation of irregularly distributed tubercles.

Remarks. Isolated hexagonal osteoderms are diagnostic of the tribe Glyptosaurini. The fact that the only member of Glyptosaurini recovered in Europe, Placosaurus, has been tentatively identified at Escarlà (see above) suggests this skull osteoderm could correspond to the same genus. However, material is clearly insufficient even for a tentative referral to the genus in the case of La Morera. As explained below, additional material (fragmentary tooth-bearing bones and body osteoderms) could belong to the same taxon, but are referred to Glyptosaurinae indet. because they are not diagnostic beyond this level (see below).

\section{Glyptosaurinae indet. \\ Figure 1.14}

Material. IPS 49769, fragment of ?body osteoderm; IPS 49749, 14 fragments of osteoderm; IPS 59566, body osteoderm (Figure 1.14); IPS 83556, one complete and four partial body osteoderms.

Description. Preserved body osteoderms are rectangular, unkeeled (or presenting a very faint keel) and bevelled. The ornamentation consists of numerous small tubercles.

Remarks. As with the glyptosaur osteoderms from Masia de l'Hereuet reported above, the recognition of Glyptosaurinae is easy, but material is not diagnostic beyond this level. The presence of an hexagonal thick skull osteoderm would point to the 
presence of a member of Glyptosaurini at $\mathrm{La}$ Morera a tribe recorded at Escarlà (see below) by the possible presence of Placosaurus. Body osteoderms are never diagnostic, so all glyptosaur material from La Morera is referred to an indeterminate glyptosaurine, except for the presence of a polygonal osteoderm that points to a member of Glyptosaurini.

\section{Indeterminate lizards (non-ophidian, non- amphisbaenian squamates)}

Material. IPS 83530, partial maxilla with five teeth; IPS 83528, tooth bearing bone with two broken teeth; IPS 49764, tooth bearing bone with one tooth; IPS 49765, tooth bearing bone with one tooth; IPS 49760, tooth bearing bone with one two teeth; IPS 49755, two fragments of tooth bearing bone; IPS 49763, tooth bearing bone with one tooth; IPS 49759, tooth bearing bone with three teeth; IPS 49757, fragment of right dentary with two broken teeth; IPS 49758, partial maxilla with four unicuspid teeth.

Remarks. Pleurodont implantation allows the identification of this material as squamate, and on the basis of tooth morphology, it can be identified as belonging to indeterminate lizards (amphisbaenians and snakes excluded). These specimens are listed here because the eventual recovery of additional better-preserved material may make them identifiable in the future.

\section{DISCUSSION}

\section{Comparison to Relevant Contemporaneous Lizard Assemblages from Europe}

Rage (2012) distinguished four distinct and sequential assemblages for the European Eocene: one for the earliest Eocene, corresponding to the MP7; one for the rest of the early Eocene, corresponding to the levels MP8+9 and MP10; one for the greatest part of the middle Eocene, ranging from to the MP11-MP15; and one for the MP16MP20, corresponding to the latest middle Eocene and the entire late Eocene. New early Eocene lberian remains described herein would correspond, based on their age as reported for the corresponding localities, to the second sequential assemblage as they belong to the levels MP8+9 and MP10. They are interesting, then, in covering a previously unrecorded period of squamate evolution in the Iberian Peninsula, where the only described early Eocene assemblage belonged to the MP7 (Silveirinha; Rage and Augé, 2003). The Catalan remains also represent the first early Eocene Iberian lizards outside Portugal (Figure 2), and correspond to just a small portion of the available material from the region, which has a good potential for Paleogene herpetology (see Bolet and Evans, 2010a, 2012a, 2013; Bolet and Augé, 2014). Additional Iberian assemblages from the middle and late Eocene, corresponding to the third and four sequential assemblages of Rage (2012), respectively, will be described elsewhere. The obtained results regarding the composition of Catalan assemblages (Figure 3) point to a great amount of homogeneity among the different levels of the early Eocene and across the known European localities of this time interval. Together with the new material here described, the composition of contemporaneous localities from the Iberian Peninsula (Silveirinha) and localities from the rest of Europe (e.g., Prémontré, Dormaal and Le Quesnoy, see Figure 2 ) is discussed below.

The same iguanid genus, and currently a single recognised species (Geiseltaliellus longicaudus) is present in most well-sampled early Eocene European localities, including Dormaal, Prémontré (Augé, 2003, 2005) and probably Silveirinha. This species extends to the middle Eocene (Augé, 2007; Rage, 2012) and the genus was long supposed to have disappeared at the Grand Coupure, but it has been subsequently reported in the late Oligocene French locality of Pech du Fraysse (Augé and Pouit, 2012) and might have been present at the German localities of Herrlingen 11 (MP28) and Herrlingen 9 (MP29)(Čerňanský et al., 2016).

Acrodontan iguanians are poorly represented by an indeterminate agamid from Masia de l'Hereuet, which is similar to the problematic taxon "Tinosaurus". A close form is known from the slightly older locality of Silveirinha (Rage and Augé, 2003), and other early Eocene localities like, again, Dormaal and Prémontré (Augé, 2003, 2005). "Tinosaurus" europeocaenus is recorded in the entire early Eocene in Europe (Rage, 2012).

Gekkotans, indeterminate in the case of the Iberian Peninsula (see Rage and Augé, 2003 and material described above), are also a constant although minor component of Eocene European lizard assemblages (Daza et al., 2014; Augé, 2005; Bolet et al., 2015). The fragmentary nature of the scarce material from the early Eocene of Catalonia precludes further discussion on the possible affinities of gekkotans from these assemblages. Specimens with a good preservation are indeed rare in the early Eocene of Europe except for those corresponding to Laonogekko lefevri recovered at Prémontré (Augé, 2003, 2005). 


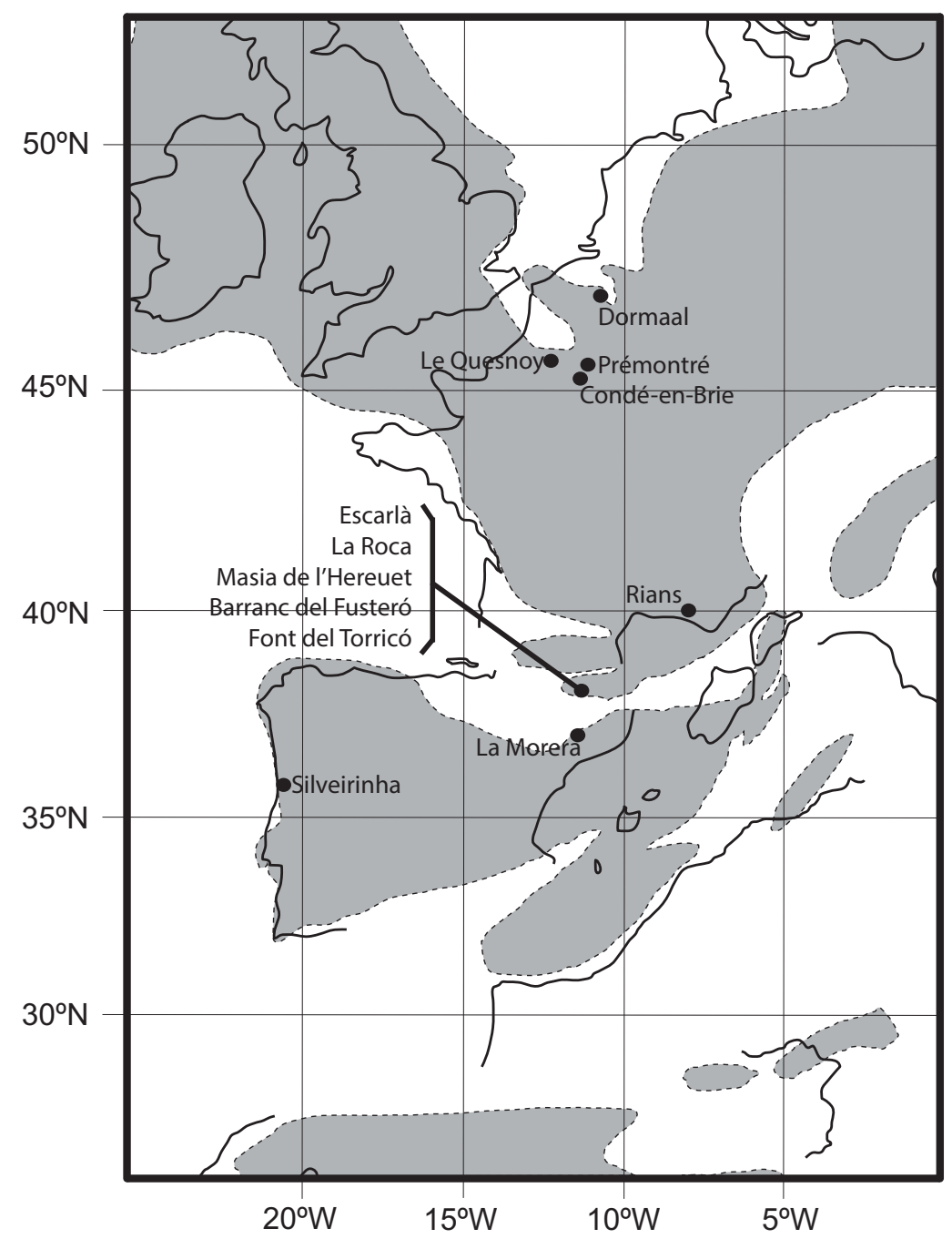

FIGURE 2. Paleogeographic map of Western Europe during the early Eocene (modified from Marandat et al., 2012) and situation of the Catalan localities yielding material described in the text and other contemporaneous European fossil sites. Note that the localities of the Southern Pyrenean Basin (Escarlà, La Roca, Masia de l'Hereuet, Barranc del Fusteró and Font del Torricó) are geographically very close, although situated in different sub-basins (see text).

"Scincomorphans" are here identified as an indeterminate scincoid (?scincid) and a lacertid-like form that could correspond to Dormaalisaurus. The lack of scincoids at Silveirinha renders the form identified at Masia de l'Hereuet as the oldest in the Paleogene Iberian record, but the putative scincoid Scincoideus and Berruva are examples of earlier forms in the European Paleogene (Augé, 2005; Folie et al., 2005), and other roughly contemporaneous forms include the scincid Axonoscincus from Prémontré (Augé, 2005). Iberian cordyliforms are not recorded until much later, in the MP17 of Sossís (Bolet and Evans, 2013). The presence of a lacertid-like form with slightly bicuspid teeth like the one found at La Morera was also reported at Silvei- rinha (Rage and Augé, 2003). The widespread and persistent genus Dormaalisaurus is known from several European localities ranging from the MP7 to the MP17 (Augé, 2005; Bolet and Evans, 2013), which renders this genus as a good candidate for the Iberian material. A second form from Silveirinha is more problematic, because it was reported as similar to Eolacerta, which is not so clearly "scincomorphan" (see Müller, 2001). Indeterminate amphisbaenians, recognised only at Masia de l'Hereuet among Catalan early Eocene localities, are also known from Silveirinha (Rage and Augé, 2003) as well as many other European localities from the Paleocene of Hainin onwards (Augé, 2005, 2012; Folie et al., 2013). Iberian amphisbae- 


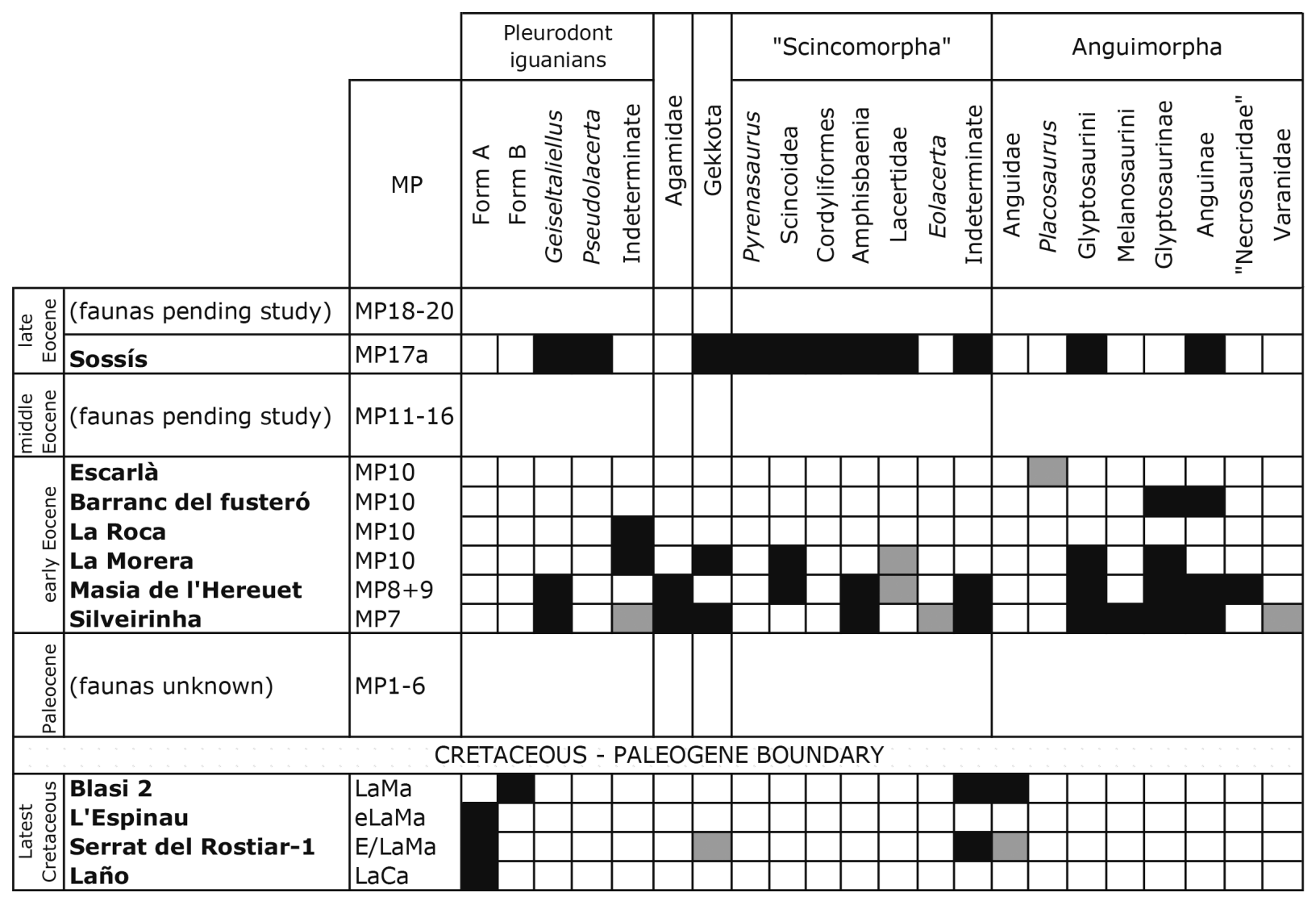

FIGURE 3. Distribution of lizard and amphisbaenian taxa from the latest Cretaceous to the late Eocene in the Iberian Peninsula. Records from Font del Torricó are omitted because its exact age inside the early Eocene is unknown. Black squares indicate unambiguous records, whereas grey squares indicate uncertainty. LaMa: Late Maastrichtian; eLaMa: earliest Late Maastrichtian; E/LaMa: Early or Late Maastrichtian; Late Campanian.

nian remains are so far too fragmentary to allow comparison to other European assemblages, but the specimens from the early Eocene are the earliest confirmed records of the family in the region.

As discussed above, anguines seem to be rare in early Eocene localities, and the low abundance of osteoderms is intriguing. The extremely small parietal from Masia de l'Hereuet is morphologically close to Ophisaurus and Ophisauriscus, and shows differences to Headhonillia and Anguis, but it does not grant a conclusive identification. The anguine Ophisauriscus has tentatively been identified at Avenay (MP8+9, Augé 2005), but it is represented by dentaries that cannot be directly compared to the Iberian material. Anguis was reported by Augé (2005) at Condé-en-Brie (MP8+9) and Prémontré (MP10), but no early Eocene record was considered by Rage (2012). It would be interesting to ascertain the identity of the early Eocene remains because they represent the earliest records of the group in Europe.
Glyptosaurs are, in contrast to anguines, well represented by osteoderms in most localities (e.g., Silveirinha, Dormaal, Prémontré; Rage and Augé, 2003; Augé, 2005). The polygonal cranial osteoderms in the Catalan localities reveal the presence of a member of Glyptosaurini. In the case of the parietal from Escarlà, it is tentatively referred to the genus Placosaurus, the only member of the tribe known for European localities (Sullivan et al., 2012), from which it cannot be distinguished. No glyptosaur elements from Catalonia are referred to "Melanosaurini," but its presence cannot be ruled out because some elements (poorly preserved tooth-bearing bones and body osteoderms) are not diagnostic to the tribe level. Moreover, this tribe was reported from the MP7 of the Portuguese locality of Silveirinha (Rage and Augé, 2003). Regarding the rest of Europe, glyptosaurs are known from the earliest to the latest Eocene in a great number of localities, including Prémontré, Dormaal, and Le Quesnoy among those of the early Eocene. Regarding the latter, the former 
referral to cf. Paraplacosauriops quercyi (Augé and Sullivan, 2006) at Dormaal has been subsequently replaced by a referral to ?Placosaurus ragei (Sullivan et al., 2012).

Regarding varanoids (i.e., "necrosaurs," varanids, and helodermatids), the latter have not yet been recovered at Iberian localities. "Necrosaurs" were not identified among the material recovered at Silveirinha described by Rage and Augé (2003), and the specimens reported here represent the only record for the group in the Iberian Peninsula. They are identified on the basis of a highly characteristic osteoderm and, less certainly, a partial dentary. "Necrosaurs" are well known from the MP6 to the MP23 in European localities (Augé, 2005), and their remains are very abundant in some localities. A possible varanid was reported from Silveirinha (Augé and Rage, 2003), but they seem to be absent from contemporaneous Catalan localities.

The assemblages described herein thus contribute to an interpretation of an homogeneous lizard and amphisbaenian fauna in Europe through the following additions to the Iberian early Eocene: 1) they reveal the presence of "necrosaurs," a typical Paleogene taxon the absence of which was anomalous in the Iberian Peninsula; 2) they reveal the presence of Scincoidea (possibly Scincidae) in the Iberian early Eocene (their earliest Iberian record in the Paleogene previously was late Eocene in age); 3) they confirm the extension of the range of a series of taxa known in the MP7 of Silveirinha to the rest of the early Eocene (MP7+8 and/or MP10) such as pleurodont and acrodont iguanians, gekkotans, lacertids, amphisbaenians, and glyptosaurs. At the level reached by current identifications of fossil lizards from the Iberian Peninsula no great difference is yet evident between the only known fauna of the MP7 and those from the MP8+9 and MP10. However, this might be explained by several non-exclusive reasons. European assemblages reported by Rage (2012) for differentiating both faunas contained elements not studied here, such as amphibians and snakes. The study of a reduced fraction of contemporaneous assemblages is less likely to recover the same amount of differences. Rage (2012, figure 2) reveals that of the 20 taxa reported for the MP7MP10 interval, 10 belong to both sequential assemblages, six only correspond to the second one, and only four to the first one. Only two lizards reported from the MP7 are absent from later assemblages: "Scincoid A" and Campinosaurus from Dormaal (Rage, 2012). Moreover, these two taxa are exclusive of the locality where they were found, and thus of a potential limited distribution. They are thus also absent from the MP7 locality from the Iberian Peninsula, and this results in an increased similarity between assemblages from the MP7 and those from the MP8+9 and MP10 in the Iberian Peninsula. Of those taxa that appear in the MP8+9 and/or MP10 and are absent from the MP7, only three are lizards: Laonogekko lefevrei, Axonoscincus sabatieri, and Eolacerta robusta. Rage and Augé (2003) reported the presence of gekkotans in the Iberian MP7, and the present study reports the presence of the group also in the MP10. However, it is not possible to state if forms from the different assemblages correspond to different taxa or not. Scincoids seem to be absent from the MP7 of Silveirinha but present in latter assemblages. However, scincoids seem to be present along the entire early Eocene in Europe, although represented by several different taxa. Although this would reveal a difference between Iberian assemblages of the MP7 and MP8+9 and MP10, it should be taken into account that such difference only relies in the lack of scincoids in the single MP7 locality. Finally, the possible presence of Eolacerta was reported for the MP7 of Silveirinha, but material is not conclusive, and the taxon has not been identified at MP8+9 and MP10 localities described herein.

\section{Comparison to Earlier Iberian Assemblages}

Despite a poor Paleocene record, European assemblages from outside the Iberian Peninsula provide some clues on the origin of the different groups in that region. Pleurodont and acrodont iguanians, gekkotans, and glyptosaurs lack a Paleocene record in Europe, and so have been interpreted as Eocene immigrants into the continent, whereas "necrosaurs" and amphisbaenians, present in Paleocene assemblages from the region, would be survivors through the Paleocene/ Eocene boundary (Rage, 2012, 2013). Note, however, that pleurodont iguanians, gekkotans, and anguids have a pre-K/Pg boundary record, and their absence in the Paleocene either corresponds to an artifact of the fossil record or to a momentary retrieval of such groups. If Scincoideus is a scincoid (Folie et al., 2005, but see Smith and Gauthier [2013] for an alternative interpretation), then this family was also present in the European Paleocene. Scincoid-like forms (paramacellodids and other taxa like Saurillodon, which has been interpreted as a scincid) were present in the Iberian Late Jurassic, but are rare in Early Cretaceous and absent in Late Cretaceous localities. The record of 
scincids unequivocally starts again in the MP10 in Europe (with some earlier tentative records), whereas lacertids are not known prior to the early Eocene (Augé, 2005), where they are first recorded. It is difficult to state which is the first cordyliform because some of the Eocene forms are represented by very fragmentary material, and because it is difficult to differentiate paramacellodids from cordyliforms (or other scincoids) in earlier assemblages. Anguinae is not known in Europe before the MP7 of Dormaal (Augé, 2005), but it is worth noting that the identity of late Cretaceous Iberian anguids at a lower level is unknown. In any case, anguines seem to be absent from well-sampled Paleocene localities from Europe, and typical anguine osteoderms are lacking from Mesozoic and Paleocene localities. Further considerations on the origin of Eocene taxa in the Iberian Peninsula is hampered by the scarce Paleocene squamate record. Because of the paucity of the Iberian Paleocene record, early Eocene assemblages like those described herein provide the best chances for evaluating the recovery of faunas after the $\mathrm{K} / \mathrm{Pg}$ extinction, but mainly record a migratory event where many taxa from other continents (North America and possibly Asia and/or Africa) joined the poorly diverse Paleocene taxa in Europe. Moreover, the Late Cretaceous Iberian record is also limited, with just a few localities presenting some lizard diversity (Rage, 1999; Blain et al., 2010; Pereda-Suberbiola et al., 2015; Blanco et al., 2016) and always yielding fragmentary material. Such a poor record of lizard assemblages around the K/Pg boundary strongly contrasts with the wellknown assemblages from the Late Jurassic (Seiffert, 1973; Broschinski, 2000) and Early Cretaceous (Evans and Barbadillo, 1997, 1998, 1999; Bolet and Evans, 2010b, 2011, 2012b; Evans and Bolet, 2016), yielding much better preserved specimens and more diverse assemblages. Iberian taxa from the Late Jurassic and Early Cretaceous belong to Paramacellodidae (possibly stem-scincoids), ?Scincidae, Anguimorpha, and to a collection of forms with a certain tendency to fall at the stem of "Scleroglossa" (Bolet and Evans, 2010b). Paramacellodids are represented by the same two genera (Paramacellodus and Becklesius) in the Late Jurassic (where they are found with possible scincids Chalcidosaurus and Saurillodon, see Kosma, 2004) and the Early Cretaceous of the lberian Peninsula, but in the latter they appear as a minor component of the lizard assemblages because the non-paramacellodid diversity is much higher (Bolet and Evans, 2010b). The ?scincid
Saurillodon (its position as a scincoid is well supported) is represented by numerous species (Kosma, 2004). Anguimorphs are represented by Dorsetisaurus in the late Jurassic and the nonpythonomorph varanoid Arcanosaurus in the early Cretaceous (e.g., Broschinski, 2000; Houssaye et al., 2013a). The Iberian taxa recovered on the stem of 'Scleroglossa' include, Pedrerasaurus, Eichstaettisaurus, Hoyalacerta, Scandensia, and Meyasaurus, but the latter two may represent more derived 'scleroglossans' (Bolet and Evans, 2010b, 2011). The Iberian record of lizards from this age is exceptional both in terms of diversity and preservation of the specimens, mainly those recovered from lithographic limestones.

Late Cretaceous material is, in contrast with that of the Early Cretaceous, relatively rare in the Iberian Peninsula, but the lack of forms shared by localities in the Early and Late Cretaceous suggests a replacement of faunas. Late Cretaceous assemblages confirm that archaic Early Cretaceous lizard faunas were completely replaced by taxa that are much easier to accommodate in modern groups, including possible iguanians, 'scincomorphs', anguids, ?xenosaurs and varanoid anguimorphs, and crown group snakes (Rage, 1999; Blain et al., 2010; Narváez and Ortega, 2010; Pereda-Suberbiola et al., 2015; Blanco et al., 2016; Pérez-García et al., 2016). Even within the Late Cretaceous, there are differences between the composition of first and second halves of this period. However, in many cases assemblages are so poor in squamate remains that they are clearly underestimating the actual diversity and, accordingly, it is difficult to evaluate the degree of replacement of such faunas. For example, the easily identifiable multicuspid dentition of the lizard from the Campanian-Maastrichtian of Lo Hueco (Narváez and Ortega, 2010) is unknown in any other locality. The same is true for varanoids like those from the same locality (Houssaye et al., 2013b). The strongly bicuspid "scincomorph" from Serrat del Rostiar (Blanco et al., 2016) or the ?xenosaur with a tricuspid robust dentition from Armuña (Pérez-García et al., 2016) would be exclusive of the localities where they were described. In contrast, a tricuspid iguanid is shared by Laño, Blasi 2, Serrat del Rostiar-1, and L'Espinau, although it is possible that two different forms are recorded (Blanco et al., 2016). The latest Iberian Mesozoic lizard assemblages (Serrat del Rostiar-1, Blasi 2, and l'Espinau) are all situated in the southern Pyrenees (Blanco et al., 2016), geographically close to the early Eocene lizard assem- 
blages described herein. The overall composition of Late Cretaceous and early Eocene assemblages (Figure 3 ) is similar at the family level, but with differences that are outlined below. Similarities include the presence of pleurodont iguanians, possible gekkotans (less clearly identified in the Late Cretaceous), bicuspid "scincomorphans," anguids, and snakes (see Blain et al., 2010 and Blanco et al., 2016 for latest Cretaceous assemblages). At the family level, then, acrodont iguanians, lacertids, amphisbaenians, glyptosaurs, "necrosaurs," and anguines are additions of early Eocene faunas. The case of scincoids and varanoids stands out in that scincoids are present in earlier Mesozoic assemblages but not in the late Cretaceous of the Iberian Peninsula, and Iberian terrestrial varanoids exist, but did not reach the latest Cretaceous. If all the above identifications are correct, it seems that these groups are recorded in the Iberian Peninsula before and after the $\mathrm{K} / \mathrm{Pg}$ extinction, but there would be a large gap between the last Mesozoic and the first Cenozoic forms. This gap would be much larger for scincoids and varanoids than for anguids and iguanids, whose gap only comprises the Paleocene. As explained above, it is important to note that the Paleocene gap could be an artefact because no Iberian lizard remains of this age are known, but these same groups are also absent from known Paleocene European localities, rendering this explanation less parsimonious.

Rage $(2012,2013)$ stated that squamates were not strongly affected by the $\mathrm{K} / \mathrm{Pg}$ event because the Late Cretaceous faunas were already impoverished. However, and despite some similarities at the family level, specific taxa are, as far as have been identified, different at both sides of the $\mathrm{K} / \mathrm{Pg}$ boundary, which suggests a strong replacement in Europe. In the Iberian Peninsula the lack of Paleocene precludes an evaluation of such replacement, because the early Eocene faunas already seem to show a mixture of survivors from the Paleocene in Europe, and immigrant taxa that reached the continent in the early Eocene. Iberian late Cretaceous iguanians probably belong to two different forms both possessing tricuspid teeth (Blanco et al., 2016). However, one bears spatulate crowns (present in the fossil sites of Laño, Serrat del Rostiar and L'Espinau; see Blanco et al., 2016) and the other one (present at Blasi-2; see Blain et al., 2010) does not. The former is clearly absent from early Eocene assemblages, whereas the second one is difficult to differentiate from the Eocene Geiseltaliellus (albeit the fragmentary nature of Late Cretaceous specimens allows for lit- tle more than an identification as a pleurodont iguanian on the basis of the general tooth morphology of the group). The possible presence of gekkotans in the late Cretaceous (Blanco et al., 2016) was based on a small frontal from Serrat del Rostiar. Thus, more diagnostic material (dentaries) from Catalan Eocene localities cannot be directly compared to the Maastrichtian specimen. Acrodont iguanians (in this case an agamid close to "Tinosaurus," but see Smith et al., 2011 for a discussion on this taxon) are poorly diverse and scarce at early Eocene localities (Rage and Augé, 2003; see material described above), but their characteristic dentition allows us to state that they are absent in pre-Eocene European localities described so far. Scincoids and lacertids are absent from late Cretaceous Iberian localities (in fact lacertids do not appear in Europe until the early Eocene [Augé, 2005]). The "scincomorphan" taxon from Serrat del Rostiar 1 (Blanco et al., 2016) has not been yet identified, but its strong bicuspidy differentiates it from Eocene "scincomorphans," so this form apparently did not cross the $\mathrm{K} / \mathrm{Pg}$ boundary. Among anguimorphans, the presence of an anguid in the Late Cretaceous is suggested by some vertebrae from Laño, Blasi 2, and Serrat del Rostiar (but see Rage, 1999 for an interpretation of the vertebrae from Laño as belonging to an amphisbaenian). The eventual recovery of skull elements or osteoderms would help to identify the Iberian Late Cretaceous anguids, but the fragmentary vertebrae recovered so far are not diagnostic enough to serve for a better identification. The lack of osteoderms, despite representing negative evidence, argues against the presence of anguines in the Iberian late Cretaceous. Amphisbaenians, once thought to be present in late Cretaceous Iberian assemblages (Rage, 1999), are now considered to appear as late as the early Eocene (first at Silveirinha and later, as reported here, at Masia de l'Hereuet). The earliest records of Iberian glyptosaurs, "necrosaurs," and varanids correspond to this same age, the early Eocene. Of these, glyptosaurs and "necrosaurs" are clearly absent from Mesozoic localities, whereas Iberian Middle and Late Cretaceous varanoids are clearly different from the varanoids recovered in the early Eocene.

An analysis of the pre- and post-K/Pg boundary Iberian assemblages suggests, despite the low resolution of identifications in some cases, a faunal turnover. The lack of Paleocene assemblages, however, precludes an analysis of the timing for the recovery of the faunas after the extinction. The lberian early Eocene records document a phase of 
strong fluxes of immigration into Europe from North-America and, less clearly, Africa and Asia, joining the fauna already established in the continent along the Paleocene.

\section{Comparison to Later (Late Eocene) Iberian Assemblages}

Iberian middle Eocene lizard assemblages exist in the ICP collections (Bolet and Evans, $2010 \mathrm{~b}$ ), but they have not yet been studied in detail, precluding direct comparison to the faunas described herein. They will be interesting in complementing the few known European middle Eocene assemblages (see Rage, 2012) and are expected to provide some clues on the way lberian lizard assemblages evolved along the Eocene. Current comparison to younger Paleogene assemblages is, thus, limited to the late Eocene and, more specifically, to the diverse assemblage of Sossís, the only one of this age described so far from the Iberian Peninsula (Bolet and Evans, 2013). The main changes in lizard composition that are observable between Iberian localities from the early and late Eocene are (data for the late Eocene from Bolet and Evans, 2013, except where indicated): 1) the lack of acrodont iguanians in the late Eocene; 2) the presence of the pleurodont iguanian Pseudolacerta in the late Eocene; 3 ) the presence of "scincomorphans" lacking earlier records, including the lacertid Gracilicerta, an amblyodont indeterminate lacertid, the scincoid Pyrenasaurus (see Bolet and Augé, 2014) and indeterminate cordyliforms at Sossís; 4) the replacement of an anguine close to Ophisaurus or Ophisauriscus by one similar to Headonhillia, at least as suggested by the two parietals recovered at these localities; 5 ) the confirmed presence of both "Melanosaurini" and Glyptosaurini in the early Eocene, but only of Glyptosaurini in the late Eocene; 6) the lack of "necrosaurs" in the late Eocene; and 7) the lack of non- "necrosaur" varanoids in the late Eocene, if truly present in the early Eocene. Thus, the presence of pleurodont iguanians, gekkotans, lacertids, scincoids (?scincids), amphisbaenians, anguines, and glyptosaurines seems to be continuous through the Iberian Eocene, a view confirmed by the record of such groups in undescribed localities of the middle Eocene (Bolet and Evans, 2010a; personal obs.). Agamids are so far unknown from the Iberian Paleogene except for this period of the early Eocene (MP7-MP8+9) and are in fact only later recorded in the Iberian Peninsula in the Pliocene and Early Pleistocene (Bailon, 1991; Blain and Bailon, 2006; Delfino et al., 2008; Blain et al.,
2014, 2016). Lacertids have formed an essential portion of European lizards since the early Eocene, but the decline of other groups has resulted in their complete dominance of present faunas. Amphisbaenians, gekkotans, and anguines represent a minor component of present Iberian faunas. Varanoids, glyptosaurs, and pleurodont iguanids are nowadays absent from the Iberian Peninsula (glyptosaurs and "necrosaurs" died out in the late Eocene and Oligocene, respectively, see Rage [2012]).

\section{Paleobiogeography}

The new early Eocene assemblages present, as was evident for the previously described assemblage of Silveirinha (Rage and Augé, 2003), a marked Laurasian pattern. Iguanids and glyptosaurs probably share a North American origin with helodermatids, the latter being present in Europe but strangely absent at the Iberian Peninsula. The oldest amphisbaenians come from the early Paleocene of North America, and this group has been claimed to have had its origin in that continent (Gauthier et al., 2012; Longrich et al., 2015). However, amphisbaenians are recorded in Europe as early as the middle Paleocene, and these early forms are already clearly different from the North American forms. The origin of early Eocene gekkotans in Europe is difficult to ascertain, as Mesozoic (see Caldwell et al., 2015 and Blanco et al., 2016) and early Paleogene (Augé, 2005; Daza et al., 2014) material referred to the group is scarce and fragmentary and of uncertain affinities. Agamids and varanids may be of Laurasian or African origin (Rage, 2012), although the Eocene varanid Saniwa is shared by North-American and European localities. The origin of lacertids seems to be Europe where they have their earliest fossil records. The point of origin for "necrosaurs" strongly depends on which taxa are included in this group, which is otherwise often regarded as paraphyletic. Scincoids, and possibly scincids, were present in the Mesozoic of Europe and specifically of the Iberian Peninsula, but their presence through the Cretaceous and Paleocene might have been discontinuous. They have a global distribution in the case of scincids, but cordyliforms have an African origin.

The composition of Iberian early Eocene assemblages, consisting in the associations described herein from Catalonia plus the MP7 locality of Silveirinha in Portugal reveals a strong homogeneity with the rest of European assemblages. No endemic forms have been reported so far from Iberian early Eocene lizard localities. How- 
ever, the fragmentary nature of most specimens usually precludes identification at the species level. In any case, this suggests that barriers did not preclude interchanges between faunas from the lberian Peninsula and those of the rest of Europe. This contrasts with the situation in the latest middle and earliest late Eocene, when at least the assemblages from western and central lberia showed a marked endemism as revealed by the composition of mammal associations (Badiola et al., 2009).

\section{CONCLUSIONS}

The new assemblages described here complement the only previously described early Eocene locality having yielded lizards in the Iberian Peninsula. The new faunas confirm the presence of pleurodont iguanians (Geiseltaliellus and maybe a second indeterminate iguanid), agamids (a form similar to "Tinosaurus"), gekkotans, lacertid-like scincomorphans (a form similar to Dormaalisaurus), amphisbaenians, anguines, and glyptosaurines (a form similar to Placosaurus) along the entire early Eocene. They also assess the presence of taxa typical of contemporaneous localities from the rest of Europe missing from Silveirinha, such as scincoids (?scincids) and "necrosaurs." Considered together, the faunal composition of early Eocene Iberian localities is comparable to those from the rest of Europe, although localities are poor in number of specimens and/or preservation of the fossils. It is noticeable the lack of helodermatids at Iberian localities, although this could be related to an artifact of the fossil record, mainly taking into account that helodermatids are not especially abundant in the localities where they occur (see Smith and Gauthier, 2013). The composition of Iberian faunas points to a great homogeneity of early Eocene localities across Europe and along the different MP levels. There seems to be little variation regarding lizard and amphisbaenian assemblages from the earliest (MP7) to the latest (MP10) early Eocene, and in any case the same patterns have usually been identified at regions with a better record in Europe. These assemblages contribute, together with other recently described associations (Sossís; Bolet and Evans, 2013; Bolet and Augé, 2014) and additional localities from the middle and late Eocene yet to describe (Bolet and Evans, 2010a), to a better understanding of the interesting Iberian Eocene faunas. A description of lizard assemblages from the Eocene will provide insights on long debated hypotheses of the endemic nature of Iberian Eocene assemblages, mainly regarding its timing and restriction to western and central Iberia from the middle and late Eocene. The assemblages yet to be describe will provide clues on this and other important issues in the near future.

\section{ACKNOWLEDGMENTS}

This work received support from grant CGL2014-54373-P (Ministerio de Economía y Competitividad, Spain/FEDER, UE), 2014 SGR 416 GRC and Cerca Programme / Generalitat de Catalunya, Catalonia. The author wants to thank S. Moyà-Solà for the opportunity to study all the material included in this work, and J. Marigó, R. MinwerBarakat, and J. Femenias-Gual for providing information on material and localities and access to the material from Font del Torricó, and the new material from Masia de l'Hereuet. J. Klembara and J.-C. Rage provided useful comments on the identity of some lizard remains. S.E. Evans is acknowledged for her help and support through the elaboration of the author's PhD thesis, including the first steps toward the completion of this publication. Comments by $\mathrm{H}$.-A. Blain and an anonymous reviewer provided valuable inputs that highly improved this work.

\section{REFERENCES}

Antunes, M.T., Casanovas, M.L., Cuesta, M.A., Checa, L., Santafé, J.V., and Agustí, J. 1997. Eocene mammals from Iberian Peninsula, p. 337-352. In Aguilar, J.P., Legendre, S., and Michaux, J. (eds.), Actes du Congrés BiochroM'97. Mémoires et Travaux de I'Institut de Montpellier (EPHE) 21. Montpellier, France.

Augé, M. 2003. La faune de Lacertilia (Reptilia, Squamata) de l'Éocène inférieur de Prémontré (Bassin de Paris, France). Geodiversitas, 25:539-574.

Augé, M. 2005. Évolution des lézards du Paléogène en Europe. Mémoires du Muséum national d'Histoire naturelle, Paris, 192:1-369.

Augé, M. 2007. Past and present distribution of iguanid lizards. Arquivos do Museu Nacional, Rio de Janeiro, 65:403-416.

Augé, M. 2012. Amphisbaenians from the European Eocene: a biogeographical review. Palaeobiodiversity and Palaeoenvironments, 92:425-443.

Augé, M. and Pouit, D. 2012. Presence of iguanid lizards in the European Oligocene Lazarus taxa and fossil abundance. Bulletin de la Société Géologique de France, 183:653-660.

Augé, M. and Smith, R. 1997. Les Agamidae (Reptilia, Squamata) du Paléogène d'Europe occidentale. Belgian Journal of Zoology, 127:123-138. 
Augé, M. and Smith, R. 2002. Nouveaux Lacertidae (Reptilia, Squamata) de l'Eocène inférieur europée. Belgian Journal of Zoology, 131:3-15.

Augé, M. and Sullivan, R.M. 2006. A new genus, Paraplacosauriops (Squamata, Anguidae, Glyptosaurinae), from the Eocene of France. Journal of Vertebrate Paleontology, 26:133-137.

Badiola, A., Checa, L., Cuesta, M.A., Quer, R., Hooker, J.I., and Astibia, H. 2009. The role of new Iberian finds in understanding European mammalian biogeography. Geologica Acta, 7:243-258.

Bailon, S. 1991. Amphibiens et reptiles du Pliocène et du Quaternaire de France et d'Espagne: mise en place et évolution des faunes. Unpublished PhD Thesis, Université de Paris VII, Paris, France.

Berg, D.E. and Crusafont, M. 1970. Note sur quelques Crocodiliens de l'Eocène prépyrénaique. Acta Geológica Hispánica, 5:54-57.

Blain, H.-A. and Bailon, S. 2006. Catalogue of Spanish Plio-Pleistocene amphibians and squamate reptiles from the Museu de Geologia de Barcelona. Treballs del Museu de Geologia de Barcelona, 14:61-80.

Blain, H.-A., Bailon, S. and Agustí, J. 2016. The geographical and chronological pattern of the herpetofaunal Pleistocene extinctions on the Iberian Peninsula. Comptes Rendus Palevol, 15:731-744.

Blain, H.-A., Bailon, S., Agustí, J., Piñero-García, P., Lozano-Fernández, I., Sevilla, P., López-García, J.M., Romero, G., and Mancheño, M.Á. 2014. Youngest agamid lizards from Western Europe (Sierra de Quibas, Spain, Early Pleistocene). Acta Palaeontologica Polonica, 59:873-878.

Blain, H.-A., Canudo, J.-I., Cuenca-Bescós, G., and López-Martínez, N. 2010. Amphibians and squamate reptiles from the latest Maastrichtian (Upper Cretaceous) of Blasi 2 (Huesca, Spain). Cretaceous Research, 31:433-446.

Blanco, A., Bolet, A., Blain, H.-A., Fondevilla, V., and Marmi, J. 2016. Late Cretaceous (Maastrichtian) amphibians and squamates from northeastern Iberia. Cretaceous Research, 57:624-638.

Bolet, A. and Augé, M. 2014. A new miniaturized lizard from the late Eocene of France and Spain. The Anatomical Record, 297:505-515.

Bolet, A., Daza, J.D., Augé, M., and Bauer, A.M. 2015. New genus and species names for the Eocene lizard Cadurcogekko rugosus Augé, 2005. Zootaxa, 3985:265-274.

Bolet, A. and Evans, S.E. 2010a. New Eocene squamate assemblages from Spain. III International Palaeontological Congress, London, Book of Abstracts, 93.

Bolet, A. and Evans, S.E. 2010b. A new lizard from the Early Cretaceous of Catalonia (Spain) and the Mesozoic lizards from the Iberian Peninsula. Cretaceous Research, 31:447-457.

Bolet, A. and Evans, S.E. 2011. New material of the enigmatic Scandensia, an Early Cretaceous lizard from the Iberian Peninsula. Special Papers in Palaeontology, 86:99-108.
Bolet, A. and Evans, S.E. 2012a. The lizard assemblage of Sossís (Late Eocene, Catalonia, Spain): preliminary results. In Royo-Torres, R., Gascó, F., and Alcalá, L. (eds.), 10th Annual Meeting of the European Association of Vertebrate Palaeontologists. ¡Fundamental!, 20:23-24.

Bolet, A. and Evans, S.E. 2012b. A tiny lizard (Lepidosauria, Squamata) from the Lower Cretaceous of Spain. Palaeontology, 55:491-500.

Bolet, A. and Evans, S.E. 2013. Lizards and amphisbaenians (Reptilia, Squamata) from the late Eocene of Sossís (Catalonia, Spain). Palaeontologia Electronica, 16.1.8A:1-23 palaeo-electronica.org/content/ 2013/412-eocene-squamates-from-spain

Bonaparte, C.L.J.L. 1831. Saggio di Una Distribuzione Metodica Degli Animali Vertebrati. Antonio Boulzaler, Rome.

Broschinski, A. 2000. The lizards from the Guimarota mine, p. 59-68. In Martin, T. and Krebs, B. (eds.), Guimarota: a Jurassic Ecosystem. Verlag Dr. Friedrich Pfeil, München.

Caldwell, M.W., Nydam, R.L., Palci, A., and Apesteguía, S., 2015. The oldest known snakes from the Middle Jurassic-Lower Cretaceous provide insights on snake evolution. Nature Communications, 6:6996.

Camp, C.L. 1923. Classification of the lizards. Bulletin of the American Museum of Natural History, 48:289481.

Čerňanský, A., Klembara, J., and Müller, J. 2016. The new rare record of the late Oligocene lizards and amphisbaenians from Germany and its impact on our knowledge of the European terminal Palaeogene. Palaeobiodiversity and Palaeoenvironments, 96:559587.

Checa, L. 1995. Los Perisodáctilos (Ungulata, Mammalia) del Eoceno Catalán. PhD Thesis, University of Barcelona, Spain.

Checa Soler, L. and Casanovas Cladellas, M.L. 1990. El Eoceno Español: los yacimientos y sus faunas. Paleontologia i Evolució, 23:17-39.

Cope, 1864. On the characters of the higher groups of Reptilia Squamata, and especially of the Diploglossa. Proceedings of the Academy of Natural Sciences of Philadelphia, 1864:224-231.

Crusafont-Pairó, M. and Golpe-Posse, J.M. 1974. Primates fósiles de España. Miscellanea Alcobé, 1974:2944.

Crusafont-Pairó, M. and Rosell, J. 1966. Primera datación de los tramos superiores del Eoceno continental de la cuenca de Ager (Provincia de Lérida). Notas y Comunicaciones del Instituto Geológico y Minero de España, 83:79-91.

Cuvier, G. 1817. Le règne animal distribué d'après son organisation, pour servir de base à l'histoire naturelle des animaux et d'introduction à l'anatomie comparée. Chez Déterville et chez Crochard, Paris.

Daza, J.D., Bauer, A.M., and Snively, E.D. 2014. On the fossil record of the Gekkota. The Anatomical Record, 297:433-462. 
Delfino M., Kotsakis T., Arca M., Tuveri C., Pitruzzella G., and Rook, L. 2008. Agamid lizards from the PlioPleistocene of Sardinia (Italy) and an overview of the European fossil record of the family. Geodiversitas, 30:641-656.

Estes, R., de Queiroz, K., and Gauthier, J. 1988. Phylogenetic relationships within Squamata, p. 119-281. In Estes, R. and Pregill, G. (eds.), Phylogenetic Relationships of the Lizard Families. Stanford University Press, California.

Evans, S.E. and Barbadillo, L.J. 1997. Early Cretaceous lizards from Las Hoyas, Spain. Zoological Journal of the Linnean Society, 119:23-49.

Evans, S.E. and Barbadillo, L.J. 1998. An unusual lizard (Reptilia: Squamata) from the Early Cretaceous of Las Hoyas, Spain. Zoological Journal of the Linnean Society, 124:235-265.

Evans, S.E. and Barbadillo, L.J. 1999. A shortlimbed lizard from the Lower Cretaceous of Spain. Special Papers in Palaeontology, 60:73-85.

Evans, S.E. and Bolet, A. 2016. Chapter 17, Squamata, p. 156-161. In Poyato-Ariza, F. and Buscalioni, A.D. (eds.), Las Hoyas: a Cretaceous Wetland. A Multidisciplinary Synthesis after 25 Years of Research on an Exceptional Fossil Lagerstätte from Spain. Dr. Pfeil Verlag, München.

Femenias-Gual, J., Minwer-Barakat, R., Marigó, J., and Moyà-Solà, S. 2016a. Agerinia smithorum sp. nov., a new early Eocene primate from the Iberian Peninsula. American Journal of Physical Anthropology, 161:116-124.

Femenias-Gual, J., Minwer-Barakat, R., Marigó, J., and Moyà-Solà, S. 2016b. New dental material and redescription of Agerinia roselli (Primates, Adapiformes) from Les Saleres (early Eocene, NE Iberian Peninsula). Palaeontologia Electronica, 19.2.17A palaeoelectronica.org/content/2016/1468-redescription-ofa-roselli

Folie, A., Sigé, B., and Smith, T. 2005. A new scincomorph lizard from the Palaeocene of Belgium and the origin of Scincoidea in Europe. Naturwissenschaften, 92:542-546.

Folie, A., Smith, R., and Smith, T. 2013. New amphisbaenian lizards from the early Paleogene of Europe and their implications for the early evolution of modern amphisbaenians. Geologica Belgica, 16:227-235.

Fürbringer, M. 1900. Zur vergleichenden anatomie des Brustschulterapparates und der Schultermuskeln. Jenaische Zeitschrift, 34:215-718.

Gauthier, J.A., Kearney, M., Maisano, J.A., Rieppel, O., and Behlke, D.B. 2012. Assembling the squamate tree of life: perspectives from the phenotype and the fossil record. Bulletin of the Peabody Museum of Natural History, 53:3-308.

Gervais, P. 1852. Zoologie et paléontologie françaises (animaux vertébrés) ou Nouvelles recherches sur les animaux vivants et fossiles de la France. Arthus Bertrand, Paris.
Gray, J.E. 1825. A synopsis of the genera of Reptiles and Amphibia, with a description of some new species. Annals of Philosophy, Series 2, 10:193-217.

Gray, J.E. 1827. A synopsis of the genera of saurian reptiles, in which some new genera are indicated and the others reviewed by actual examination. Annals of Philosophy, New Series, 2:54-58.

Gray, J.E. 1844. Catalogue of the Tortoises, Crocodiles, and Amphisbaenians in the Collection of the British Museum. British Museum of Natural History, London.

Hoffstetter, R., 1943. Varanidae et Necrosauridae fossiles. Bulletin du Muséum National d'Histoire Naturelle, 15:134-141.

Houssaye, A., Bardet, N., Narváez, I., and Ortega, F. 2013b. Squamate finding in "Lo Hueco" (Late Campanian-Early Maastrichtian, Cuenca Province, Spain): the second non-marine pythonomorph lizard. Paläontologische Zeitschrift, 87:415-422.

Houssaye, A., Rage, J.C., Torcida Fernández-Baldor, F., Huerta Hurtado, P., Bardet, N., and Pereda Suberbiola, X. 2013a. A new varanoid squamate from the Early Cretaceous of Burgos, Spain. Cretaceous Research, 41:127-135.

Jones, M.E.H., Anderson, C.L, Hipsley, C.A., Müller, J., Evans, S.E., and Schoch, R.S. 2013. Integration of molecules and new fossils supports a Triassic origin for Lepidosauria (lizards, snakes, and tuatara). BMC Evolutionary Biology (Section: Phylogenetics and Phylogeography), 13:208.

Klembara, J. and Green, B. 2010. Anguimorph lizards (Squamata, Anguimorpha) from the Middle and Late Eocene of the Hamphsire Basin of Southern England. Journal of Systematic Palaeontology, 8:97129.

Kosma, R. 2004. The dentitions of recent and fossil scincomorphan lizards (Lacertilia, Squamata) - Systematics, Functional Morphology, Paleoecology. PhD Thesis, University of Hannover, Hannover. Digital publication, www.tib.uni-hannover.de/DigitaleBibliothek/ElektronischeHochschulschriften.html.

Kuhn, O. 1944. Weitere Lacertilier, insbesondere Iguaniden aus dem Eozän des Geiseltales. Paläontologische Zeitschrift, 23:360-366.

Longrich, N., Vinther, J., Pyron, R.A., Pisani, D., and Gauthier, J.A. 2015. Biogeography of worm lizards (Amphisbaenia) driven by end-Cretaceous mass extinction. Proceedings of the Royal Society B, 282:20143034.

Marandat, B., Adnet, S., Marivaux, L., Martinez, A., Vianey-Liaud, M., and Tabuce, R. 2012. A new mammalian fauna from the earliest Eocene (Ilerdian) of the Corbières (Southern France): palaeobiogeographical implications. Swiss Journal of Geosciences, 105:417-434.

Marigó, J., Minwer-Barakat, R., Moyà-Solà, S., and López-Torres, S. 2012. First record of Plesiadapiformes (Primates, Mammalia) from Spain. Journal of Human Evolution, 62:429-433. 
Marigó, J., Minwer-Barakat, R., and Moyà-Solà, S. 2013. Nievesia sossisensis, a new anchomomyin (Adapiformes, Primates) from the early Late Eocene of the southern Pyrenees (Catalonia, Spain). Journal of Human Evolution, 64:473-485.

Marigó, J., Roig, I., Seiffert, E.R., Moyà-Solà, S., and Boyer, D.M. 2016. Astragalar and calcaneal morphology of the middle Eocene primate Anchomomys frontanyensis (Anchomomyini): implications for early primate evolution. Journal of Human Evolution, 91:122-143.

Marigó, J., Susanna, I., Minwer-Barakat, R., MadurellMalapeira, J., Moyà-Solà, S., Casanovas-Vilar, I., Robles, J.M., and Alba, D.M. 2014. The primate fossil record in the Iberian Peninsula. Journal of Iberian Geology, 40:179-211.

Marsh, O.C. 1872. Preliminary description of new Tertiary reptiles. Parts I and II. American Journal of Science, 101:447-458.

Minwer-Barakat, R., Marigó, J., and Moyà-Solà, S. 2012. Pseudoloris cuestai, a new microchoerine (Primates, Omomyidae) from the middle Eocene of the Iberian Peninsula. Journal of Vertebrate Paleontology, 32:407-418.

Minwer-Barakat, R., Marigó, J., and Moyà-Solà, S. 2013. Redescription and designation of a neotype for Pseudoloris reguanti Crusafont-Pairó, 1967, an Eocene primate from the Iberian Peninsula. American Journal of Physical Anthropology, 151:245-251.

Müller, J. 2001. Osteology and relationships of Eolacerta robusta, a lizard from the middle Eocene of Germany (Reptilia, Squamata). Journal of Vertebrate Paleontology, 21:261-278.

Narváez, I. and Ortega, F. 2010. Análisis preliminar de los restos de Iguanidae indet. del Cretácico Superior de lo Hueco (Fuentes, Cuenca). Cidaris, 30:205-210.

Oppel, M. 1811. Die Ordnung, Familien und Gattungen der Reptilien als Prodrom einer Naturgeschichte derselben. Lindauer, München.

Ortega, F., Escaso, F., and Pérez-García, A. 2010. Mesoeucrocodilos zifodontos del Eoceno de la Península Ibérica, p. 191-192. In Santos, A., Mayoral, E., Meléndez, G., Silva, C.M. de and Cachão, M. (eds.), III Congreso Ibérico de Paleontología XXVI Jornadas de Paleontología de la Sociedad Española de Paleontología. Lisboa, Portugal, 7 a 10 de Julio de 2010. Ibéria en el centro de las relaciones atlántico-mediterráneas / A lbéria no centro das relações atlanto-mediterrânicas. Libro de Resúmenes / Livro de Resumos. Servicio de Reprografía, Universidad de Zaragoza (Publicaciones del Seminario de Paleontología de Zaragoza, SEPAZ, 9), Zaragoza.

Pereda-Suberbiola, X., Corral, J.C., Astibia, H., Badiola, A., Bardet, N., Berreteaga, A., Buffetaut, E., Buscalioni, A.D., Cappetta, H., Cavin, L., Díez Díaz, V., Gheerbrant, E. , Murelaga, X., Ortega, F., Pérez-García, A., Poyato-Ariza, F., Rage, J.C., Sanz, J.L., and Torices, A. 2015. Late Cretaceous continental and marine vertebrate assemblages of the Laño Quarry
(Basque-Cantabrian Region, Iberian Peninsula): an update. Journal of Iberian Geology, 41:101-124.

Pérez-García, A. 2012. Berruchelus russelli gen. et sp. nov., a paracryptodiran turtle from the Cenozoic of Europe. Journal of Vertebrate Paleontology, 32:545556.

Pérez-García, A., Murelaga, X., Cardiel Lazuela, J., Badiola, A., and Díaz-Berenguer, E., 2013. Presence of several clades of continental turtles in the Lutetian (Middle Eocene) of the Sobrarbe Formation (Ainsa Basin, South-Central Pyrenees, Northeast Spain). Geologica Belgica, 16:311-319.

Pérez-García, A., Ortega, F., Bolet, A., Escaso, F., Houssaye, A., Martínez-Salanova, J., de Miguel Chaves, C., Mocho, P., Narváez, I., Segura, M., Torices, A., Vidal, D., and Sanz, J.L., 2016. An update on the knowledge of the Spanish upper Campanian vertebrate site of Armuña (Segovia Province). Cretaceous Research, 57:591-623.

Pyron, R.A., Burbrink, F.T., and Wiens, J.J. 2013. A phylogeny and revised classification of Squamata, including 4161 species of lizards and snakes. BMC Evolutionary Biology, 13:93.

Rage, J.-C. 1999. Squamates (Reptilia) from the Upper Cretaceous of Laño (Basque Country, Spain). Estudios del Museo de Ciencias Naturales de Álava, 14(spec. num. 1):121-133.

Rage, J.-C. 2012. Amphibians and squamates in the Eocene of Europe: what do they tell us? Palaeobiodiversity and Palaeoenvironments, 92:445-457.

Rage, J.-C. 2013. Mesozoic and Cenozoic squamates of Europe. Palaeobiodiversity and Palaeonvironments, special issue 93(4):517-534.

Rage, J.-C. and Augé, M. 2003. Amphibians and squamate reptiles from the lower Eocene of Silveirinha (Portugal). Ciências da Terra, 15:103-116.

Rage, J.-C. and Augé, M. 2015. Valbro, a new site of vertebrates from the early Oligocene (MP 22) of France (Quercy). III - Amphibians and squamates. Annales de Paléontologie, 101(1):29-41.

Richter, A. 1994. Lacertilia aus Unteren Kreide von Uña und Galve (Spanien) und Anoual (Marokko). Berliner Geowissenschaftliche Abhandlungen, 14:1-147.

Seiffert, J. 1973. Upper Jurassic lizards from central Portugal. Memóres Serviços Geológicos de Portugal (Nova Série), 22:1-85.

Smith, K.T. 2011a. The evolution of mid-latitude faunas during the Eocene: Late Eocene lizards of the Medicine Pole Hills reconsidered. Bulletin of the Peabody Museum of Natural History, 52(1):3-105.

Smith, K.T. 2011b. On the phylogenetic affinity of the extinct acrodontan lizard Tinosaurus. Bonner Zoologische Monographien, 57:9-28.

Smith, K.T. and Gauthier, J.A. 2013. Early Eocene lizards of the Wasatch Formation near Bitter Creek, Wyoming: diversity and paleoenvironment during an interval of Gglobal warming. Bulletin of the Peabody Museum of Natural History 54:135-230. 
Smith, K.T., Schaal, S., Sun, W., and Li, C.T. 2011. Acrodont iguanians (Squamata) from the middle Eocene of the Huadian Basin of Jilin Province, China, with a critique of the taxon "Tinosaurus." Vertebrata PalAsiatica, 49:67-84.

Sullivan, R.M. 1979. Revision of the Paleogene Genus Glyptosaurus (Reptilia, Anguidae). Bulletin of the American Museum of Natural History, 163(1):1-72.

Sullivan, R.M. and Augé, M., 2006. Redescription of the holotype of Placosaurus rugosus GERVAIS 18481852 (Squamata, Anguidae, Glyptosaurinae) from the Eocene of France and a revision of the genus. Journal of Vertebrate Paleontology, 26:127-132.

Sullivan, R.M., Augé, M., Wille, E., and Smith, R. 2012. A new glyptosaurine lizard from the earliest Eocene of Dormaal, Belgium. Bulletin Societé Géologique de France, 183:627-633.

Sullivan, R.M., Keller, T., and Habersetzer, J. 1999. Middle Eocene (Geiseltalian) anguid lizards from Geisel- tal and Messel, Germany. I. Ophisauriscus quadrupes Kuhn, 1940. Courier Forschungsinstitut Senckenberg, 216:97-129.

Townsend, T.M., Larson, A., Louis, E., and Macey, J.R. 2004. Molecular phylogenetics of Squamata: the position of snakes, amphisbaenians, and dibamids, and the root of the squamate tree. Systematic Biology, 53:735-757.

Vidal, N. and Hedges, S.B. 2009. The molecular evolutionary tree of lizards, snakes, and amphisbaenians. Comptes Rendus Biologie, 332:129-139.

Wiens, J.J., Kuczynski, C.A., Townsend, T., Reeder, T.W., Mulcahy, D.G., and Sites, J.W. Jnr. 2010. Combining phylogenomics and fossils in higher-level squamate reptile phylogeny: molecular data change the placement of fossil taxa. Systematic Biology, 59:674-688. 